\title{
RESEARCH PAPER \\ PREPARATION AND CHARACTERIZATION OF ACTIVATED CARBONS FROM ALBIZIA SAMAN POD
}

\author{
G. D. Akpen, M.I. Aho and N. Baba \\ Department of Civil Engineering, University of Agriculture, Makurdi, Nigeria. \\ Corresponding author: deliakpen@yahoo.com
}

\begin{abstract}
Activated carbon was prepared from the pods of Albizia saman for the purpose of converting the waste to wealth. The pods were thoroughly washed with water to remove any dirt, air-dried and cut into sizes of 2-4 cm. The prepared pods were then carbonised in a muffle furnace at temperatures of $400^{\circ} \mathrm{C}, 500^{\circ} \mathrm{C}, 600^{\circ} \mathrm{C}, 700^{\circ} \mathrm{C}$ and $800^{\circ} \mathrm{C}$ for 30 minutes. The same procedure was repeated for 60, 90, 120 and 150 minutes respectively. Activation was done using impregnation ratios of 1:12, 1:6, 1:4, 1:3, and 1:2 respectively of $\mathrm{ZnCl}_{2}$ to carbonised Albizia saman pods by weight. The activated carbon was then dried in an oven at $105^{\circ} \mathrm{C}$ before crushing for sieve analysis. The following properties of the produced Albizia saman pod activated carbon (ASPAC) were determined: bulk density, carbon yield, surface area and ash, volatile matter and moisture contents. The highest surface area of $1479.29 \mathrm{~m}^{2} / \mathrm{g}$ was obtained at the optimum impregnation ratio, carbonization time and temperature of $1: 6,60$ minutes and $500^{\circ} \mathrm{C}$ respectively. It was recommended that activated carbon should be prepared from Albizia saman pod with high potential for adsorption of pollutants given the high surface area obtained.
\end{abstract}

Keywords: Albizia saman pod, activated carbon, carbonization, temperature, surface area

\section{INTRODUCTION}

Heavy metal contamination of water bodies is of public health concern because of their toxic effects on the environment and human health. Some metals such as silver, mercury, cadmium and copper are toxic even at very low levels. Among these toxic heavy metals, cadmium, mercury and lead have been called "the big three" and are in the lime light due to their major impact on the environment (Volesky, 1994;
Volesky and Holan, 1995).

Adsorption is a cost-effective method for the removal of metals (Balkose and Baltacioglu, 1992; Shah et al., 2009; Rahmani et al., 2009) from aqueous solutions. The major advantage of an adsorption system for water pollution control is that it involves less investment in terms of both initial equipment and land cost, simple design and easy operation and no ef- 
45

Akpen et al.

fect of toxic substances compared to other treatment processes (Markovska et al., 2006). Activated carbon was used as an adsorbent for removal of heavy metal pollutants from wastewater and has proved to be effective.

The conventional activated carbon used in adsorption is usually expensive (Mckay, 1981; 1982). This has stimulated interest in examining the feasibility of using cheaper raw materials. Agricultural adsorbents such as coffee husk (Kumar, 2006), peanut shells (Wafwoyo et al., 1999), mango seed shells (Akpen et al., 2011, 2015), bagasse (Azhar et al., 2005), rice husk (Kumar and Bandyopadhyay, 2006), wheat bran (Dupond and Guillon, 2000), cassava waste (Abia et al., 2003) and sawdust (Argun et al.,2007) have been developed. The use of Albizia saman (alternatively called Samanea saman) pod as an adsorbent for the removal of cadmium in adsorption columns has not been reported. Albizia saman pods are renewable agricultural wastes available abundantly at little or no cost. The elemental composition of Albizia saman pod presented in Table 1 shows a high carbon content of $43.61 \%$ indicating that it is a good precursor for production of activated carbon.

The use of Albizia saman pods as an adsorbent will reduce solid wastes in the environment by converting the agricultural waste to wealth, boost Albizia saman plantation, provide employment and hence, improve standard of living of the people. Similarly, cadmium (II) is of great public health concern because of its toxic effects such as itai-itai disease, cancer, ulceration of the skin, liver and kidney damage in animals and humans. The effective removal of cadmium from industrial wastewaters of industries such as phosphate fertilizer and nickelcadmium batteries manufacturing industries will improve public health.

\section{MATERIALS AND METHODS}

Albizia saman pods sampling and preparation of adsorbent

The Albizia saman pods were collected from Makurdi Local Government Area of Benue State, Nigeria. The pods were air- dried and broken to free the seeds. The pods were then thoroughly washed with water to remove any dirt, air-dried and cut into sizes of $2-4 \mathrm{~cm}$ before carbonization.

\section{Carbonization}

Carbonization was performed in a muffle furnace (model; ME 45/12 sob) manufactured by Arnold Schröder (industrieöfen $\mathrm{GmbH}$ ), Germany. Nine hundred grams $(900 \mathrm{~g})$ of the airdried sample (Albizia Saman Pod) was weighed into clean stainless steel containers and placed in the furnace and maintained at a pre-set temperature of $500^{\circ} \mathrm{C}$ for 30 minutes. This was repeated for $60,90,120$ and 150 minutes. The carbonization was repeated at different temperatures of $400,600,700$ and $800^{\circ} \mathrm{C}$ and at various times of $30,60,90,120$ and $150 \mathrm{~min}$ utes. This was done to determine the optimum carbonization temperature and time.

Table 1: Elemental composition of Albizia saman (Samanea saman)

\begin{tabular}{ll}
\hline Element & Composition $\mathbf{( \% )}$ \\
\hline carbon & 43.61 \\
Hydrogen & 5.45 \\
Nitrogen & 6.28 \\
Oxygen & 44.66 \\
\hline
\end{tabular}

Source: (Mythili et al., 2013) 


\section{Activation}

Carbonised samples weighing $400 \mathrm{~g}$ each were mixed in standard solutions $(0.25 \mathrm{M}, 0.5 \mathrm{M}, 0.75$ $\mathrm{M}, 1 \mathrm{M}$, and $1.25 \mathrm{M})$ of zinc chloride $\left(\mathrm{ZnCl}_{2}\right)$ and allowed to soak for 24 hours at room temperature. Thereafter, the liquid was discarded and the activated carbon dried in an oven at $105^{\circ} \mathrm{C}$ over night before crushing for sieve analysis. The standard solutions of zinc chloride were prepared by dissolving $34.07 \mathrm{~g}$, $68.145 \mathrm{~g}, 102.22 \mathrm{~g}, 136.29 \mathrm{~g}$, and $170.36 \mathrm{~g}$ of anhydrous zinc chloride in $1000 \mathrm{ml}$ of distilled water respectively. This resulted in impregnation ratios of 1:12, 1:6, 1:4, 1:3, and 1:2 respectively of $\mathrm{ZnCl}_{2}$ to carbonised Albizia saman pods by weight.

\section{Characterisation of activated carbon pro- duced}

\section{Sieve analysis}

The activated carbon produced was crushed and sieved through sieve sizes of $850,600,425$, 300,150 and $75 \mu \mathrm{m}$ and those retained on sieves $75,150,300,425$ and $600 \mu \mathrm{m}$, were used for the adsorption studies.

\section{Carbon yield}

As in Fapetu, (2000), the weight, $\mathrm{W}_{0}$, of each air dried Albizia saman pod sample was measured. The carbon yield, $\mathrm{Y}_{\mathrm{ch}}$ was calculated according to equation 1 .

$\mathrm{Y}_{\mathrm{ch}}=100 \mathrm{~W}_{\mathrm{ch}} / \mathrm{W}_{0}$

Where, $\mathrm{W}_{\mathrm{ch}}$ is the weight of carbon retrieved from the furnace and $\mathrm{W}_{0}$ is the weight of air dried Albizia saman pod sample.

\section{Bulk density $\left(\mathrm{g} / \mathrm{cm}^{3}\right)$}

Bulk density was estimated using the method of Ahmedna et al. (1997), which consisted of placing a known weight of ASPAC of sieve size of $0.03 \mathrm{~cm}$ in a $25 \mathrm{ml}$ cylinder to a specified volume and tapping the cylinder for at least 1-2 min and measuring the volume of carbon after settling. The bulk density was calculated as:
$\mathrm{B}_{\mathrm{d}}=\mathrm{W}_{\mathrm{s}} / \mathrm{V}_{\mathrm{s}}$

Where $\mathrm{B}_{\mathrm{d}}=$ bulk density $\left(\mathrm{g} / \mathrm{cm}^{3}\right), \mathrm{W}_{\mathrm{s}}=$ weight of dry ASPAC sample $(\mathrm{g})$, and $\mathrm{V}_{\mathrm{s}}=$ volume $\left(\mathrm{cm}^{3}\right)$ of packed sample.

\section{Surface area}

The surface area was determined by the method described by Rouquerol et al. (1999) thus: A s $\left(\mathrm{m}^{2} / \mathrm{g}\right)=6 /\left(\mathrm{B}_{\mathrm{d}} \mathrm{x} \mathrm{D}_{\mathrm{s}}\right) \ldots \ldots$.

Where $A_{s}=$ surface area, $B_{d}=$ bulk density $(\mathrm{g} /$ $\left.\mathrm{m}^{3}\right)$ and $\mathrm{D}_{\mathrm{s}}=$ particle diameter $(\mathrm{m})$.

\section{Ash content determination}

As in Dara, (1991), two grams of the dried ASPAC sample was placed into a porcelain crucible of known weight and transferred into a preheated muffle furnace set at a temperature of $900^{\circ} \mathrm{C}$. The furnace was left on for one hour after which the crucible and its content were transferred to a desiccator and allowed to cool. The crucible and content were reweighed and the weight noted. During this test, the crucible was left open. Ash content (dry basis) was calculated as equation 4 :

$\operatorname{Ash}(\%)=\frac{w_{i}-w_{f}}{w_{i}} \times 100 \quad \ldots .$.

Where; $\mathrm{W}_{\mathrm{i}}$ is the initial weight of crucible and ASPAC sample and $W_{f}$ is the final weight of crucible and ASPAC sample.

\section{Volatile matter}

As in Hesse, (1997), two grammes of oven dried ASPAC was placed in a closed crucible. It was then heated up to $900^{\circ} \mathrm{C}$ and maintained for 10 minutes in the furnace. The crucible was then cooled in a desiccator and reweighed. The difference in weight $\left(\mathrm{W}_{\mathrm{p}}\right)$ was noted and the volatile content determined using equation 5 .

$V_{\mathrm{e}}=\frac{2-w_{p}}{w_{d}} \times 100$

Where $\mathrm{V}_{\mathrm{c}}=$ volatile content $(\%), \mathrm{W}_{\mathrm{p}}=$ difference in weight and $\mathrm{W}_{\mathrm{d}}=$ oven dry weight of $2 \mathrm{~g}$ 
of ASPAC.

\section{Moisture content}

A sample of activated carbon was weighed into a petri-dish. It was well spread on the dish. It was then heated at $105^{\circ} \mathrm{C}$ for $3 \mathrm{hrs}$. The petridish was left open during the heating process. After heating, the petri-dish was removed, cooled in a desiccator and then weighed and the moisture content calculated thus:

$\mathrm{M}_{\mathrm{ch}}(\%)=\left[\left(\mathrm{W}_{0}-\mathrm{W}_{1}\right) \times 100\right] / \mathrm{W}_{0} \ldots \ldots$

Where $\mathrm{M}_{\mathrm{ch}}=$ moisture content, $\mathrm{W}_{0}=$ original weight of sample before heating $(\mathrm{g})$ and $\mathrm{W}_{1}=$ final weight of sample after heating for $3 \mathrm{hr}(\mathrm{g})$.

\section{RESULTS AND DISCUSSIONS}

Carbonization temperature and time for formation of Albizia Saman pod activated carbon (ASPAC)

For ASPAC produced after $30 \mathrm{~min}$ and $60 \mathrm{~min}$ of processing, the surface area of ASPAC increased from $675.904 \mathrm{~m}^{2} / \mathrm{g}$ at $400{ }^{\circ} \mathrm{C}$ to $1194.743 \mathrm{~m}^{2} / \mathrm{g}$ at $500^{\circ} \mathrm{C}$ and decreased to $458.926 \mathrm{~m}^{2} / \mathrm{g}$ at $800^{\circ} \mathrm{C}$ (Fig. 1). Among the activation temperatures investigated, that of $500^{\circ} \mathrm{C}$ gave the highest surface area in the activated carbon (Fig. 1). At higher temperatures, such as $800^{\circ} \mathrm{C}$, more ash was produced because the burn-off was higher causing the formation of tars that filled the pores of the samples. Increasing temperature should ordinarily lead to increase in porosity by the release of tars from the cross-linked framework formed by chemical impregnation. However, studies done by Ahmadpour and Do (1996, 1997) suggested that temperature above $500^{\circ} \mathrm{C}$ resulted in the loss of weight, shrinkage in carbon structure and porosity reduction. This trend is similar with the findings of Teng et al. (1998) and Girgis and El-Hendawy (2002). Anisuzzaman et al. (2015) also reported a similar trend on the removal of 2, 4-dichlorophenol by modified commercial activated carbon. Teng et al. (1998) stated that extensive contraction during thermal treatment collapses the porous structure.

As can be observed on Fig. 1, the surface area of ASPAC increased from $1064.396 \mathrm{~m}^{2} / \mathrm{g}$ for material processed for 30 minutes to 1194.743 $\mathrm{m}^{2} / \mathrm{g}$ after 60 minutes of processing at the temperature of $500^{\circ} \mathrm{C}$ for instance. However, the

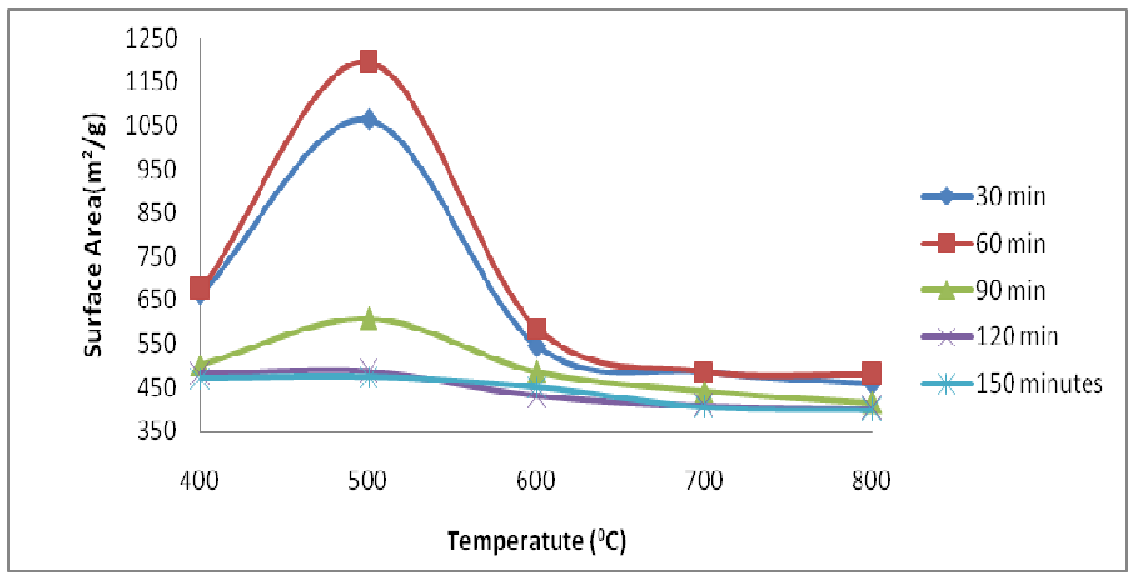

Fig. 1: Surface Area $\left(\mathrm{m}^{2} / \mathrm{g}\right)$ of ASPAC at various carbonization temperatures and times $($ Impregnation ratio $=1: 3$, Particle size $=0.03 \mathrm{~cm})$ 
surface area decreased to $471.809 \mathrm{~m}^{2} / \mathrm{g}$ for ASPAC processed for 150 minutes at the same temperature of $500^{\circ} \mathrm{C}$. The carbonization time of 60 minutes gave the highest surface area in the activated carbon. At longer times, such as 120 minutes and above, the surface area was reduced because more ash was produced because the burn-off period was longer.

\section{Effect of impregnation ratio on surface area of ASPAC}

The surface area of ASPAC was $1267.427 \mathrm{~m}^{2} / \mathrm{g}$ at impregnation ratio (IR) of $1: 12$ and it increased to $1479.29 \mathrm{~m}^{2} / \mathrm{g}$ at impregnation ratio (IR) of 1:6 for carbonization time of 60 minutes (Fig. 2). However, the surface area decreased to $1184.133 \mathrm{~m}^{2} / \mathrm{g}$ when the IR was further increased to $1: 2$. The trend was similar for other contact times investigated as the surface area increased to a maximum at IR of 1:6 and decreased with further increase in the IR. This finding is similar to the study done by Girgis and El-Hendawy (2002). Introduction of $\mathrm{ZnCl}_{2}$ beyond the optimum degree of impregnation might form an insulating layer covering the particles that will reduce the activation process and the contact with the surrounding atmos- phere (Girgis and El-Hendawy, 2002), leading to a lower surface area available for adsorption. Owabor and Iyaomolere (2013) explained that the decrease in surface area observed with increasing concentration of activating agent maybe due to a breakdown in the physical structure of the precursor caused by excessive pore pathways there by leading to shrinkage in particle size and hence surface area of the AC.

On the other hand, the lower surface area development recorded at lower IR like 1:12 was because less $\mathrm{ZnCl}_{2}$ was available for the activation reaction per given quantity of Albizia saman pod. While the increase in surface area with increase in impregnation ratio was due to increase in pore formation because of the enhanced reaction between the readily available $\mathrm{ZnCl}_{2}$ and the Albizia saman pod. A similar trend was reported by Uner et al. (2015) on the preparation of $\mathrm{AC}$ from waste watermelon rind using $\mathrm{ZnCl}_{2}$ as the activating agent.

Characteristics of Albizia Saman pod activated carbon (ASPAC)

The characterizing parameters (surface area, bulk density, ash content, volatile content,

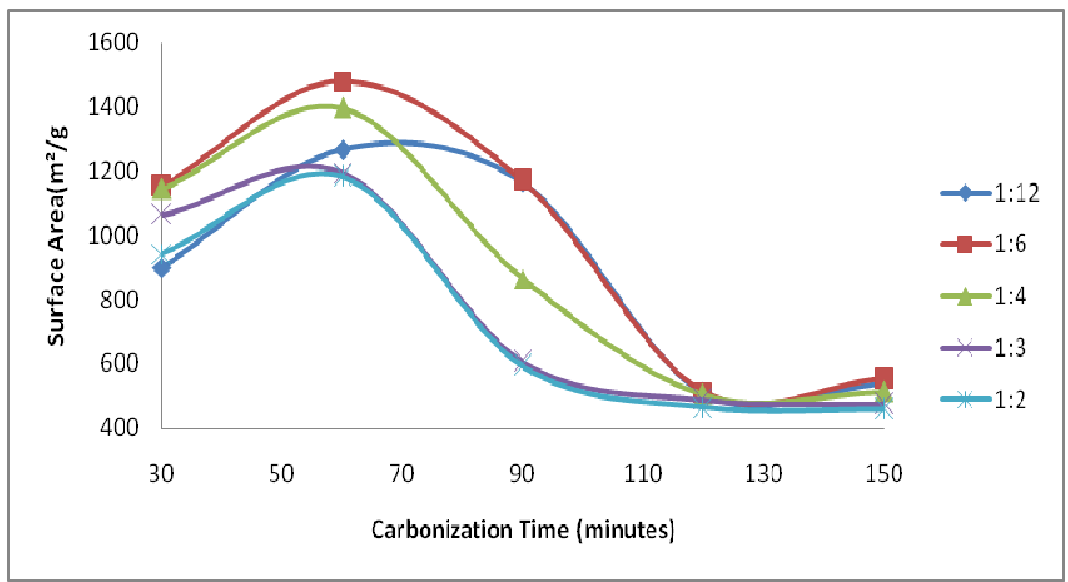

Fig. 2: Surface area of ASPAC at various impregnation ratios and times (Temperature = $500^{0} \mathrm{C}$, Particle size $=0.03 \mathrm{~cm}$ ) 
49

Akpen et al.

carbon yield, and moisture content) were investigated and the results are shown in Figs 3-5. The optimum characteristics are presented in Table 2. The bulk density was lowest at the carbonization temperature of $500^{\circ} \mathrm{C}$ for all the carbonization periods investigated (Fig. 3). The least value of $0.167 \mathrm{~g} / \mathrm{cm}^{3}$ was obtained at carbonization time and temperature of 60 minutes and $500^{\circ} \mathrm{C}$ respectively. Fig. 4 revealed a least bulk density value of $0.135 \mathrm{~g} / \mathrm{cm}^{3}$ corresponding to impregnation ratio of $1: 6$, carbonization time and temperature of 60 minutes and $500^{\circ} \mathrm{C}$ respectively. These values gave the highest surface area of the activated carbon (Fig. 2) and were chosen as the optimum values because the higher the surface area and porosity of a carbon, the higher the adsorptive capacity of the carbon (Karthikeyan et al., 2008, Aloko and

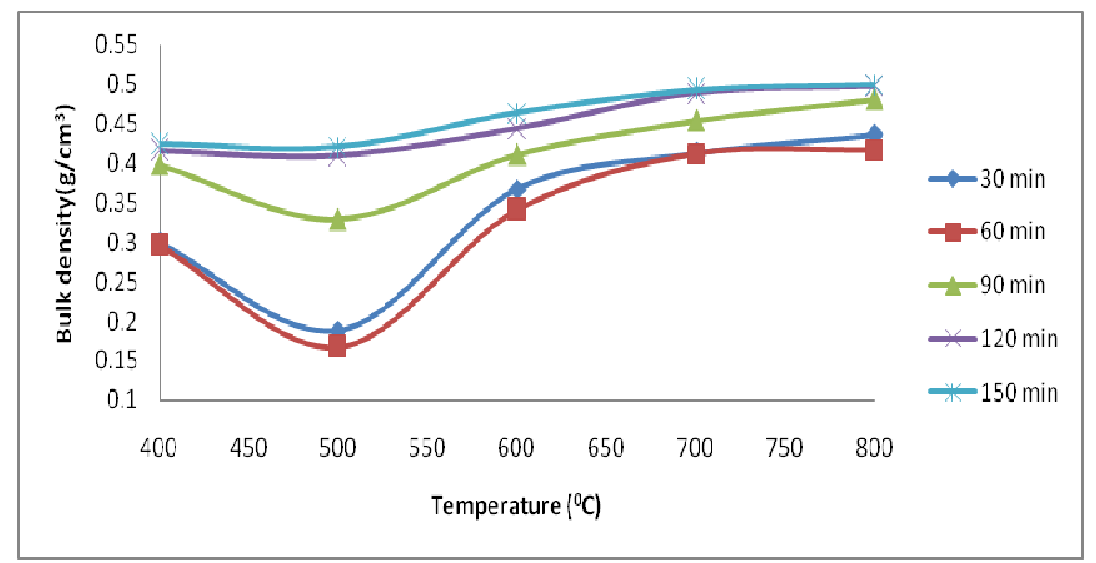

Fig. 3: Bulk Density of ASPAC at various carbonization temperatures and times $($ Impregnation ratio $=1: 3$, Particle size $=0.03 \mathrm{~cm})$

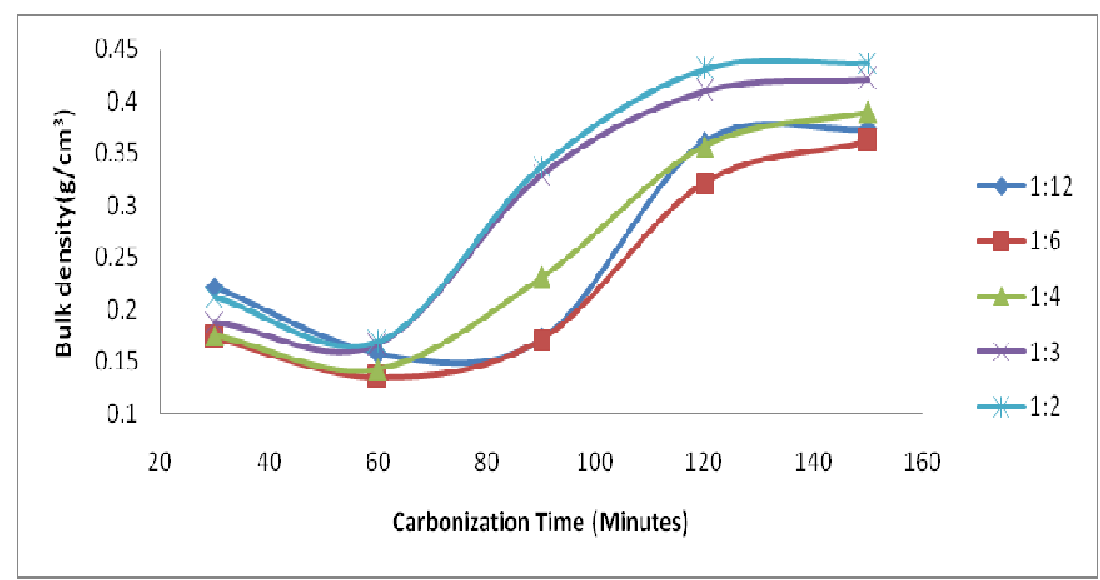

Fig. 4: Bulk density of ASPAC at various impregnation ratios and carbonization times $\left(\right.$ Temperature $=500^{\circ} \mathrm{C}$, Particle size $\left.=0.03 \mathrm{~cm}\right)$ 
Preparation of activated carbon from Albizia saman pod ... 50

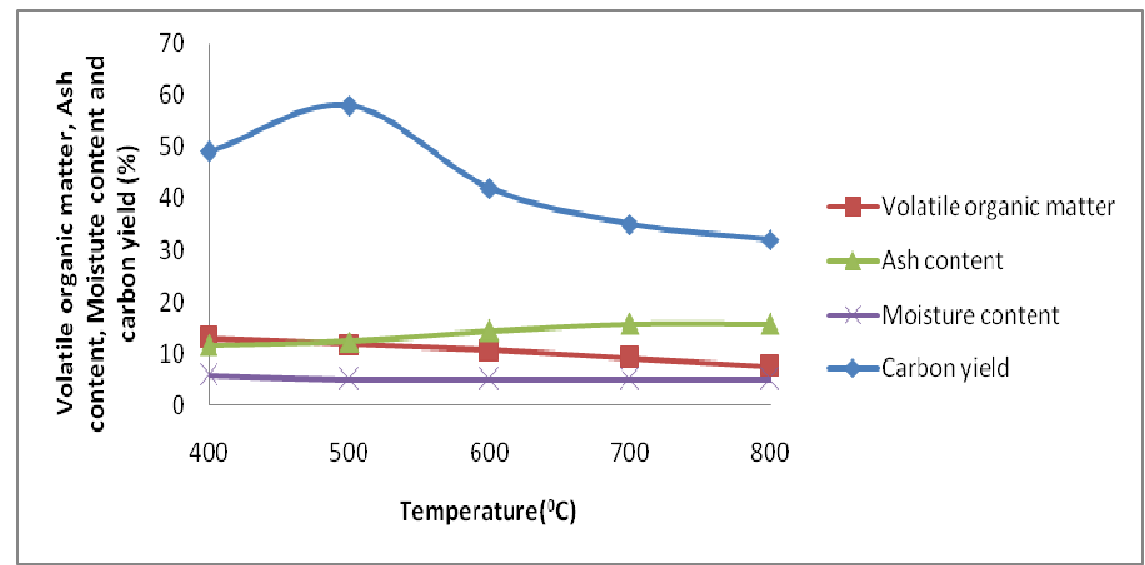

Fig. 5: Other characteristics of Albizia saman pod activated carbon (ASPAC) (Impregnation Ratio $=1: 6$, time $=60$ minutes)

Table 2: Optimum conditions for preparation/characteristics of Albizia Saman pod activated carbon (ASPAC)

\begin{tabular}{lll}
\hline S/N & Parameter & Value \\
\hline 1 & Carbonization temperature $\left({ }^{\circ} \mathrm{C}\right)$ & 500 \\
2 & Carbonization time (min.) & 60 \\
3 & Impregnation ratio & $1: 6$ \\
4 & Bulk density $\left(\mathrm{g} / \mathrm{cm}^{3}\right)$ & 0.135 \\
5 & Surface area $\left(\mathrm{m}^{2} / \mathrm{g}\right)$ & 1479.29 \\
6 & Moisture content $(\%)$ & 5 \\
7 & Carbon yield $(\%)$ & 58 \\
8 & Volatile organic matter $(\%)$ & 11.7 \\
9 & Ash content $(\%)$ & 12.35 \\
\hline
\end{tabular}

Adebayo, 2007). The result is in agreement with common knowledge that the lower the bulk density of activated carbon (AC), the higher the surface area of the carbon.

It is observed in Fig. 5 that increase in carbonization temperature resulted in a corresponding increase in ash content, while volatile matter and carbon yield generally decreased with increase in temperature. It follows that the low ash content yielded comparatively more active carbon sites for adsorption. The same result was reported by Mythili et al. (2013) and Abdullah and Gerhauser (2008). The highest carbon yield of $58 \%$ obtained at $500^{\circ} \mathrm{C}$ points to the fact that Albizia saman pod is a high yielding precursor for the production of $\mathrm{AC}$ which is in line with the results of the elemental analysis reported by Mythili et al. (2013) which gave a carbon content of $43.61 \%$. 


\section{Akpen et al}

\section{CONCLUSION AND RECOMMENDA- TIONS}

The optimum conditions for the production of activated carbon from Albizia saman pods were investigated in this research. The results obtained revealed optimum carbonization temperature and time of $500^{\circ} \mathrm{C}$ and 60 minutes respectively. The impregnation ratio of 1:6 gave the highest surface area $\left(1479.29 \mathrm{~m}^{2} / \mathrm{g}\right)$ for adsorption. Activated carbons produced at the optimum values of impregnation ratio, carbonization time and carbonization temperature had bulk density and carbon yield of $0.135 \mathrm{~g} /$ $\mathrm{cm}^{3}$ and $58 \%$ respectively. It is recommended that activated carbons should be prepared from ASPAC with high potential for adsorption of pollutants given the high surface area obtained.

\section{REFERENCES}

Abdullah, N. and Gerhauser, H. (2008). "Biooil derived from empty fruit bunches". Fuel $87: 2606-2613$

Abia, A. A., Horsfall, M. Jr. and Didi, O. (2003). "The use of chemically modified and unmodified cassava waste for the removal of $\mathrm{Cd}, \mathrm{Cu}$ and $\mathrm{Zn}$ ions from aqueous $\mathrm{s}$ o lution". Bioresource Technology, 90(3):345348 .

Ahmadpour, A. and Do, D. D. (1996). "The preparation of activated carbons from coal by chemical activation and physical activation". Carbon, 34:471-479.

Ahmadpour, A. and Do, D.D. (1997). "The preparation of activated carbon from macadamia nutshell by chemical activation". Carbon, 35:1723-1732.

Ahmedna, M., Johns, M. M., Clarke, S.J., Marshall, W. E. and Rao, R. M. (1997). Potential of agricultural by-product based activated carbons for use in raw sugar d e colorization". Journal of the Science of Food and Agriculture,75:117-124.

Akpen, G. D., Nwaogazie, I. L and Leton, T. G.
(2011). "Optimum conditions for the removal of colour from waste water by mango seed shell based activated Carbon". Indian Journal of Science and Technology, 4 (8):890894.

Akpen, G. D., Nwaogazie, I. L and Leton, T. G. (2015). Column studies on the removal of chromium from waste water by mango seed shell activated carbon. Journal of Science and Technology, 35(2):1-12.

Aloko, D. F. and Adebayo G. A. (2007). Production and characterization of activated carbon from agricultural wastes (rice-husk and corn-cob)". Journal of Engineering and Applied Sciences, 2(2):440 -444.

Anisuzzaman, S. M., Joseph, C. G., TaufiqYap, Y. H. and Krishnaiah, D. and Tay, V. V.(2015). Modification of commercial activated carbon for the removal of 2,4-dichlorophenol from simulated wastewater". King Saud University Journal of King Saud University-Science, 27: 318-330.

Argun, M. E., Dursun, S., Ozdemir, C. and Karatas, M. (2007). "Heavy metal a d s or ption by modified oak sawdust: Thermodynamics and kinetics". Journal of Harzardous Materials, 141:77-85.

Azhar, S. S., Liew. A. G., Suhardy, D., Hafiz, K. F. and Hatim, M. D. I. (2005). "Dye removal from aqueous solution by using adsorption on treated sugarcane bagasse". American Journal of Applied Sciences, 11:1499-1503.

Balkose, D. and Baltacioglu, H. (1992). "Adsorption of heavy metal cations from aqueous solution by wool fiber". Journal of Chemical Technology and Biotechnology, 54 (4):393-397.

Dara, S. S. (1991). Experiments and Calculations in Engineering Chemistry. S. Chand and Co. Ltd, New Delhi, India 
Dupond, L. and Guillon, E. (2000). Removal of hexavalent chromium with a lignocellulosicsubstrate extracted from wheat bran. Environmental Science and Technology, 37:4235 -4241 .

Fapetu, O. P. (2000). "Production of Charcoal from Tropical Biomass for Industrial and Metallurgical Processes." Nigerian Journal of Engineering Management, 1(2):34-37.

Girgis, B. S. and El-Hendawy, A. A. (2002). Porosity development in activated carbons obtained from date pits under chemical activation with phosphoric acid. Microporous and Mesoporous. Materials, 52:105-117.

Hesse, P. R. (1997). A Textbook of Soil Chemical Analysis, Illustrated. Chem. Pub. Co., John Murray: London, UK.

Karthikeyan, S., Sivakumar, P. and Palanisamy. P. N. (2008). "Novel Activated Carbons from agricultural wastes and their characterization." E-Journal of Chemistry. 5:409-426.

Kumar, U. (2006). "Agricultural products and by-products as a low cost adsorbent for heavy metal removal from water and wastewater: A review". Scientific Research and Essays, 1:033-037.

Kumar, U. and Bandyopadhyay. M. (2006). "Sorption of cadmium from aqueous solution using pretreated rice husk". Bioresource Technology., 97:104-109.

Markovska, L. T., Meshko, V. D. and Marinkovski. (2006). "Modeling of adsorption kinetics of zinc onto granular activated carbon and natural zeolite". Journal of the Serbian Chemical Society, 71(8): 957-967.

Mckay, G. (1981). Design models for adsorption system in wastewater treatment. Journal of Chemical Technology and Biotechnology,31:717 -731.
Mckay, G. (1982). "Adsorption of dyestuffs from aqueous solutions: equilibrium and contact time studies". Journal of Chemical Technology and Biotechnology, 32:759 -772.

Mythili, R., Venkatachalam, P., Subramanian, P. and Uma, D. (2013). "Characterization of bioresidues for biooil production through pyrolysis". Bioresource Technology, 138:71 -78 .

Owabor, C. N. and Iyaomolere, A. I. (2013). "Evaluation of the Influence of Salt Treatment on the Structure of Pyrolyzed Periwinkle Shell". Journal of Applied Science and Environmental Management, 17 (2): 321327.

Rahmani, K., Mahvi, A. H., Vaezi, F., Mesdaghinia, A. R., Nabizade, R. and Nazmara, S. (2009). "Bioremoval of lead by use of waste activated sludge". International Journal of Environmental Research, 3(3):471476.

Rouquerol, F., Rouquerol, J. and Sing, K. (1999). Adsorption by Powders and Porous Solids. Academic Press, London.

Shah, B. A., Shah, A. V. and Singh R. R. (2009). "Sorption isotherms and kinetics of chromium uptake from wastewater using natural sorbent material". International Journal of Environmental Science and Technology, 6 (1): 77-90.

Teng, H. S., Yeh, T. S. and Hsu, L. Y. (1998). "Preparation of activated carbon from bituminous coal with phosphoric acid activation”. Carbon, 36:1387-1395.

Uner, O., Gecgel, U. and Bayrak, Y. (2015). Preparation and characterization of mesoporous activated carbons from waste watermelon rind by using the chemical activation method with zinc chloride, Arabian Journal of Chemistry. http://doi.org/10.1016/ J.arabjc.2015.12.004 


\section{Akpen et al}

Volesky B. (1994). “Advances in biosorption of metals: selection of biomass types". FEMS Microbiology Reviews, 14(4): 291-302.

Volesky, B. and Holan, Z. R. (1995). "Biosorption of heavy metals". Biotechnol- ogy Progress, 11(3):235-250.

Wafwoyo, W., Seo, C.W. and Marshall W. E. (1999). Utilization of peanut shells as adsorbents for selected metals. Journal of Chemical Technology and Biotechnology.74: 11171121. 